Al-Huquq: Journal of Indonesian Islamic Economic Law, 3 (2), 2021: 119-142

ISSN: 2715-0003; E-ISSN 2714-5514

DOI: http://doi.org/10.19105/alhuquq.v3i2.5139

\title{
Kajian Hukum Islam Terhadap Praktik Simpan Pinjam di Kerukunan Kayubulan Kota Manado
}

\author{
Adriandi Kasim \\ (Fakultas Syariah Institut Agama Islam Negeri Manado, Jl. Dr. S.H. Sarundajang \\ Kawasan Ring Road I Kota Manado, 95128, email:)
}

\begin{abstract}
Abstrak:
Praktik simpan pinjam pada kerukunan Kayubulan menerapkan bunga sebesar sepuluh persen dan untuk anggota yang belum mampu mengembalikan pinjaman maka diwajibkan untuk membayar bunga pinjaman terlebih dahulu. Adapun rumusan masalah yang di angkat. Bagaimana praktik simpan pinjam pada kerukunan kayubulan di Kota Manado? Bagaimana tinjauan hukum Islam terhadap praktik simpan pinjam pada kerukuna Kayubulan Kota di Kota Manado? Penelitian ini bertujuan untuk mengetahui praktik simpan pinjam di kerukunan Kayubulan Wanea Kota Manado sudah berkesesuaian dengan Ijtima Ulama Komisi Fatwa Majelis Ulama (MUI) Indonesia tentang fatwa riba pada tanggal 22 syawal $1424 \mathrm{H} / 6$ Desember 2003. Penelitian ini menggunakan Jenis penelitian lapangan (field research), dengan menggunakan metode pendekatan yuridis normatif. Hasil dari penelitian menunjukan bahwa praktik simpan pinjam kerukunan Kayubulan yang bertentangan dengan hukum Islam, karena sejak awal akad telah menentukan beberapa besar bunga pinjaman dan pihak kerukunan sudah memahami haramnya umat muslim mempraktikan riba, akan tetapi mereka masih menjalankan kerukunan tersebut. (The practice of savings and loans in the "Kerukunan Kayubulan" applies an interest of ten percent and for members who have not been able to repay the loan, they are required to pay the interest on the loan first. The formulation of the problem raised. How is the practice of saving and borrowing in the "Kerukunan Kayubulan" in Manado City? How is the review of Islamic law on the practice of savings and loans in the Kayubulan Kota harmony in Manado City? This study aims to determine the practice of savings and loans in the Kayubulan Wanea harmony, Manado City is in accordance with the Ijtima Ulama Fatwa Commission of the Indonesian Ulema Council (MUI) regarding the fatwa of usury on 22 Shawwal 1424
\end{abstract}

email koresproden: adriandikasim@iain-manado.ac.id https://creativecommons.org/licenses/by-nc/4.0/ Copyright (c) 2019 by al-huquq. All Right Reserved 
H/6 December 2003. This study uses a type of field research (field research). ), using a normative juridical approach. The results of the study show that the practice of saving and borrowing in "Kerukunan Kayubulan" is contrary to Islamic law, because from the beginning the contract has determined the majority of the loan interest and the harmony party has understood that it is forbidden for Muslims to practice usury, but they still carry out the harmony)

Kata Kunci:

Hukum Islam, Simpan Pinjam, Kerukunan Kayubulan, Manado

\section{Pendahuluan}

Kerukunan kayubulan merupakan perkumpulan orang-orang yang berasal dari wilayah kayu bulan yang ada di Gorontalo namun pembentukan kerukunan ini bukan di daerah Gorontalo melainkan di Manado karena mata pencaharian mereka di kota Manado. Seiring berjalannya waktu anggota dari kerukunan ini bertambah banyak dan bersifat universal dengan anggota ber agama muslim. Jumlah anggota mencapai 1000 (seribu) yang terdiri dari ibu rumah tangga, Wirausaha, Pedagang sampai Pegawai Negeri Sipil dengan jumlah tersebut kerukunan kayubulan aktif sampai dengan saat ini. Salah satu kegiatan muamalah yang dilakukan di kerukunan kayu bulan adalah simpan pinjam.

Pada praktiknya transaksi dilakukan setiap hari minggu dengan aturan tiap perorangan hanya bisa memiliki 1 buku tabungan, tiap buku diberikan standar 100.000 (seratus ribu rupiah) dan maksimal 300.000 (tiga ratus ribu rupiah). Setiap anggota dapat mengajukan pinjaman satu minggu sebelum dana pinjaman dicairkan kegiatan pinjaman ini dilakukan dengan tujuan seperti memberikan bantuan modal kepada tiap anggota untuk menjalankan usaha mereka. Juga pencairan bisa dilakukan apabila ada jaminan seperti menginvestasikan atau menitipkan uang di dalam kerukunan kayu bulan.

Masalah yang ada dalam praktik simpan pinjam di kerukunan kayubulan adalah penetapan bunga 10 persen setiap penyetoran uang pinjaman. Penetapan bunga berlaku kepada seluruh anggota dari kerukunan kayubulan yang mengajukan pinjaman. Dalam hal ini bisa dilihat bahwa praktik simpan pinjam yang ada di kerukunan 
Kayubulan Wanea Manado dengan menetapkan bunga sebesar 10 persen setiap pengembalian maka proses kegiatan muamalah yang dilakukan oleh anggota kerunan kayu bulan.

Islam telah mengharamkan semua Tindakan manusia yang tidak dibenarkan oleh syariat dengan tujuan menjaganya dari keharaman baik terhadap perseorangan maupun kumpulan masyarakat, diantara yang diharamkan Islam adalah penggelapan, perampasan, pencurian, demikian pula barang riba. Dari uraian latar belakang di atas maka Penulis tertarik untuk melakukan penelitian yang berjudul "Tinjauan Hukum Islam Terhadap Praktik Simpan Pinjam di Kerukunan Kayu Bulan".

\section{Metode Penelitian}

Jenis penelitian lapangan dengan model penyajian dalam bentuk tulisan atau deskriptif, penelitian lapangan yang dimaksud adalah usaha untuk mendeskripsikan atau mengungkapkan fakta yang terjadi di lapangan terkait praktik simpan pinjam di Kerukunan Kayubulan Kecamatan Wanea Kota Manado. ${ }^{1}$

Penelitian ini bertumpu pada sumber data ${ }^{2}$ primer dan sumber data sekunder. Sumber data primer yang dimaksud keseluruhan keadaan yang menjadi objek penelitian yaitu meliputi : Tempat (kerukunan kayubulan kecamatan wanea kota manado provinsi Sulawesi utara), subjek (anggota kerukunan kayubulan dan ketua organisasi kayubulan).

Adapun Sumber data sekunder adalah sumber-sumber yang berasal dari tulisan seperti buku-buku relevan dengan masalah yang menjadi fokus penelitian yaitu praktik simpan pinjam yang terjadi dikerukunan Kayubulan Kecamatan Wanea Kota Manado Provinis Sulawesi utara. Di mana semua sumber data di atas diperoleh menggunakan metode wawancara, observasi, dan wawancara. Datadata di atas kemudian diolah dan dianalisis sesuai dengan prosedur reduksi data, penyajian data sampai kesimpulan.

${ }^{1}$ Lexy J. Moleong, Metodologi Penelitian Kualitatif, (Bandung: PT Remaja Rosdakarta, 2014), 4.

${ }^{2}$ Kornelius Benuf, Metodologi Penelitian Hukum sebagai Instrumen Mengurai Permasalahn Hukum Kontemporer, Jurnal Gema Keadilan Volume 7, Juni 2020, h.27 


\section{Relasi Simpan Pinjam dan Riba}

Dalam pembahasan ini akan diuraikan secara teoritik terkait dengan relasi antara teori simpan pinjam dan riba yang akan menjadi dasar atas analisa yang akan dilakukan

\section{Simpan Pinjam}

Secara Bahasa simpan diartikan meletakan barang ditempat yang aman dan baik atau sejumlah uang yang disimpan anggota dengan memperoleh jasa simpan pinjam sesuai perjanjian ${ }^{3}$. Dan pinjam berarti menggunakan barang, uang orang lain untuk diambil manfaat untuk sementara waktu. ${ }^{4}$

Simpan pinjam dalam Islam di kenal dengan istilah Ariyah. Ariyah bisa diartikan perbuatan berupa pemberian milik untuk sementara waktu oleh seseorang kepada pihak lain agar penerima dapat memanfaatkan serta mengambil manfaat dari harta yang diberikan tanpa harus membayar imbalan. Dan penerima barang harus mengembalikan barang yang diterimanya itu kepada pemberi. ${ }^{5}$

Akad ariyah secara tidak langsung berhubungan dengan akad qardh, wadiah, namun menjadi pembeda nya adalah akad ariyah bisa dilaksanakan dengan adanya jaminan seperti uang tabungan, atau harta yang dititipkan. Karakter dari ariyah yaitu harta yang dipinjamkan memiliki kesamaan dengan harta yang dititipkan. ${ }^{6}$ Ariyah termasuk salah satu bentuk transaksi tolong-menolong yang murni tanpa ada unsur-unsur profit atau komersial.

Menurut Malikiyah mendefinisikan lafaznya berbentuk Masdar yang tergolong dalam transaksi pinjam. Yang dimaksud oleh Malikiyah adalah memberikan hak menggunakan manfaat yang bersifat sementara(temporer dan tanpa imbalan. Sedangkan menurut Hambali adalah ariyah barang yang dipinjamkan, barang yang diambil dari pemiliknya dengan tujuan mengambil manfaat tanpa imbalan atau ongkos. Dan menurut Ibnu Rifa'ah yang dimaksud dengan ariyah adalah barang yang dipinjamkan merupakan barang

\footnotetext{
${ }^{3}$ Nurhaidi, “Islamisasi Koperasi Simpan Pinjam,” Jurnal ekonomi 28, no. 2 (2017).

4 Yusnita Dasim, "Mekanisme Simpan Pinjam Di Koperasi Sinar Mas dalam Perspektif Hukum Islam Studi Kasus Koperasi Simpan Pinjam Mas sinar Kelurahan calaca," Al-syir'ah 3, no. 1 (2005).

${ }^{5}$ Hasan, Berbagai Macam Transaksi dalam Islam (Jakarta: PT Raja Grafindo Persada, 2013).

6 Jamaluddin, "Konsekuensi Akad AL-Ariyah dalam Fiqh Muamalah Maliyah Perspektif Ulama Madzhab Al-Arba'ah,” Jurnal Qawanin 3, no. 2 (2018).
} 
halal dan dapat diambil manfaat oleh peminjam, serta mengembalikan barang tersebut kepada pemiliknya. ${ }^{7}$

Menurut ulama fikih mendefinisikan ariyah Sebagai kebebasan memanfaatkan barang, menurut mereka dalam transaksi ariyah materi dipinjamkan hanya manfaatnya, serta mempunyai tenggang waktu yang terbatas, Ariyah didasarkan dengan niat tolong menolong secara lahiriah. ${ }^{8}$ Dan jika ariyah mempunyai isyarat tambahan di dalamnya maka transaksi tersebut bukan lagi ariyah.

Dasar Hukum ariyah terdapat dalam firman Allah Q.S. alMaidah/5: 2 dan hadis Nabi yang diriwayatkan oleh Bukhori sebagai berikut;

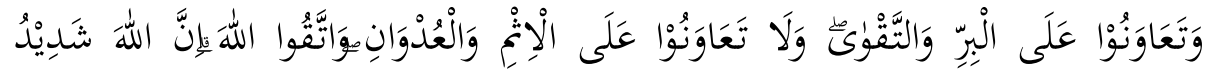

"dan tolong-menolong lah kamu dalam (mengerjakan) kebajikan dan takwa, dan jangan tolong-menolong dalam berbuat dosa dan pelanggaran. dan bertakwalah kamu kepada Allah, Sesungguhnya Allah Amat berat siksa-Nya"9

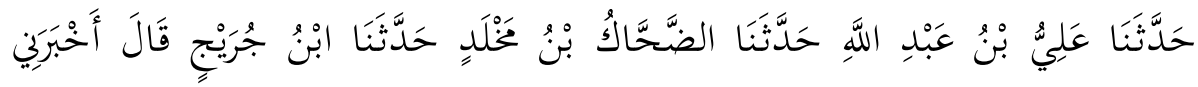

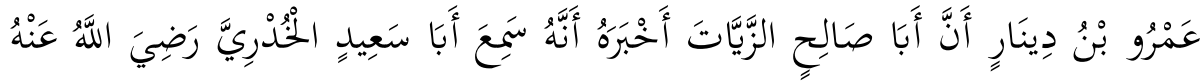

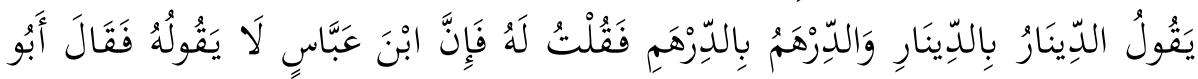

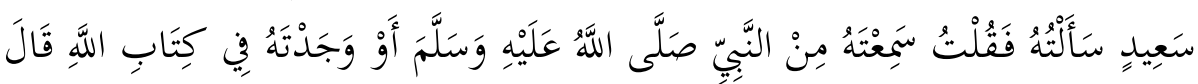

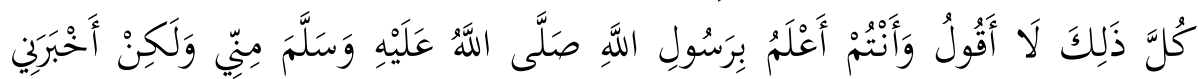

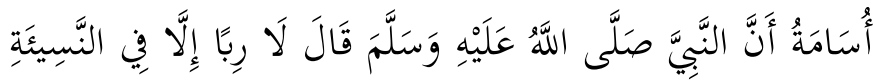

"Telah menceritakan kepada kami Ali bin Abdullah telah menceritakan kepada kami Adh Dhahhak bin makhlad telah menceritakan kepada kami Ibnu Jurajj berkata, telah mengabarkan

\footnotetext{
${ }^{7}$ Wahbah Az-Zuhaili, , Fiqih Islam Wa Adillatuhu (Jakarta: PT Gema Insani, 2011).

${ }^{8}$ Helmi Karim, Fiqih Muamalah (Jakarta: PT Raja Grafindo Persada, 2020).

${ }^{9}$ Kementerian Agama RI, Al-Qur'an dan Terjemahannya, 1 ed. (Bandung: PT Cordoba International Indonesia, 2016).
} 
kepadanya bahwa dia mendengar Abu Shalih Az zayyat mengabarkan kepadanta bahwa dia mendengar Abu Sa'id Al Khudriy radiallahu 'anhu berkata kepadanya bahwa Ibnu Abbas Radiallahu 'anhu tidak mengatakan seperti itu. Maka Abu Sa'id berkata aku pernah bertanya kepadanya dimana aku katakana apakah engaku mendengarnya dari Nabi Saw mendapatkan keterangannya dari kitab Allah. Maka dia menjawab semuanya itu aku tiak pernah mengatakannya. Dan kalian mengetahui Rasulullah Saw daripada aku namun Usamah mengabarkan kepada ku bahwa Nabi Saw berkata tidak ada riba dalam urusan pinjam meminjam."10

Hadist Riwayat Bukhari di atas menjelaskan tentang seorang muslim yang memberikan pinjaman kepada saudaranya hendaklah tidak mengenakan tambahan di dalam pinjaman tersebut, dan tidak mencari keuntungan ketika memberikan pinjaman dan hadits di atas mengenai perintah Nabi saw agar tidak memakan harta yang diperoleh dari hasil riba. Para Imam Madzhab sepakat peminjaman barang (ariyah) merupakan ibadah yang disunahkan serta diberi pahala.

Ariyah sebagai perbuatan hukum yang memuat unsur-unsur yang mesti harus dilaksnakan agar bisa terwujud transaksi ariyah itu sendiri, menurut ulama ada beberapa rukun ariyah antara lain. ${ }^{11}$

1. Orang memberikan pinjaman

2. Orang yang meminjam

3. Objek yang dipinjamkan

4. Lafal dalam pinjaman atau sighah

Ulama fikih menjelaskan, bahwa syarat-syarat dalam akad ariyah antara lain;

1. Pihak yang meinjam harus berakal dan capak bertindak atas nama hukum, karena pihak yang meminjam tidak berakal maka tidak dapat memegang amanat. Oleh karena itu, anak

\footnotetext{
${ }^{10}$ Muhammad bin Ismail Al-Bukhari, Shahih al-Bukhari, 3 ed. (Damaskus: Dar Thuqar alNujat, 2020).

${ }^{11}$ Hasan, Berbagai Macam Transaksi dalam Islam.
} 
kecil, orang gila,dungu (cacat mental) tidak bisa mengadakan akad ariyah. ${ }^{12}$

2. Objek atau barang yang akan dipinjamkan, bukan barang yang apabila dipinjamkan maka akan habis, seperti makanan dan minuman.

3. Objek atau barang yang akan dipinjamkan harus secara langsung dapat dikuasai oleh peminjam dan kemudian bisa diambil manfaat dari objek tersebut secara langsung.

Kedudukan hukum ariyah atau simpan pinjam dapat berubahubah sesuai dengan keadaan cara dan proses akadnya. Terkadan boleh, makruh, wajib dan haram, pinjam meminjam menjadi mubah jika seseorang yang meminjam bukan karena ada kebutuhan yang mendesak, tetapi menambah modal perdaganganya. Hukunya menjadi boleh jika yang meminjam yakin dapat mengembalikan pinjaman tersebut, menjadi wajib jika orang yang mengajukan pinjaman mempunyai kebutuhan yang mendesak. Seorang muslim wajib meminjam jika kondisi dalam keadaan terpaksa agar terhindar dari bahaya.

Dalam syariat Islam praktik simpan pinjam dibolehkan oleh para ulama, namun terdapat suatu kelompok yang menyalahgunakan dan memanfaatkan keadaan dalam rangka mencari keuntungan. Sebagaiamana kita ketahui ariyah tujuanya untuk saling tolong-menolong, mendatangkan kemaslahatan antar sesama manusia, bukan mencari keuntungan sepihak dengan cara mengeksploitasi harta orang lain, secara pratiknya pinjam meminjam tidak dibenarkan mengambil keuntungan oleh orang yang memberikan pinjaman, jika disyaratkan adanya tambahan atau bunga maka itu termasuk riba dan sebagaimana kita ketahui riba hukumnya adalah haram dalam Islam. ${ }^{13}$

1. Bagi peminjam

Setiap orang yang meminjam sesuatu kepada orang lain berarti peminjam memiliki hutang kepada yang berpiutang $\left(m u^{\prime} i r\right)$, setiap hutang wajib dibayar sehingga berdosalah

\footnotetext{
12 Sapludin Shiddiq, Abdul Rahman Ghazaly, Ghufron Ihsan, Fiqh Muamalat (Jakarta: Kencana, 2010).

13 Miftahul Karimi, Ensilikopedia Fiqih Muamalah dalam Pandangan 4 Madzhab (Yogyakarta: Maktabah al-Hanif, 2009).
} 
orang yang tidak membayar pinjaman,bahkan melalaikan membayar hutang juga termasuk aniaya, dan hal tersebut termasuk dalam satu perbuatan dosa. ${ }^{14}$

2. Bagi pemberi pinjaman

Bagi pemberi pinjaman, hendaknya pinjaman tersebut diberikan atas dasar adanya keinginan untuk tolong menolong.

3. Tatakrama meminjam

Islam juga telah mengatur terkait tentang tatakrama meminjam diantaranya:

a. Jika pinjaman dilakukan untuk waktu yang lama hendaknya dikuatkan dengan tulisan dari pihak berhutang dengan disaksikan dua orang saksi laki-laki atau dengan satu orang laki-laki dengan dua orang saksi wanita 15

b. Dilakukan atas dasar kebutuhan yang mendesak,

c. Pihak pemberi pinjaman hendaknya berniat memberikan potongan kepada pihak peminjam,

d. Pihak peminjam bila sudah mampu membayar hendaknya disegerakan. ${ }^{16}$

Hikmah yang dapat diambil bagi orang yang menjalankan ariyah antara lain yaitu dilapangkan rizkinya. Allah telah berjanji karena pada dasarnya harta yang dimiliki manusia itu hanyalah titipan Allah Swt semata yang diberikan untuk kemaslahatan orang banyak bukan untuk dirinya sendiri semata, maka dari itu Allah Swt manjanjikan ganjaran atau pahala yang banyak bagi orang yang menjadikan sebagian hartanya untuk dipinjamkan kepada Allah Swt dalam bentuk bersedekah kepada orang kafir dan miskin, ganjaran atau pahala tersebut adalah dilipatgandakan pinjaman tersebut. ${ }^{17}$ Selain itu, praktik ariyah juga dapat memperat tali silahturrahmi .Dengan adanya akad ariyah dapat mempererat tali hubungan persaudaraan sehingga terwujudnya kerukuan dan kedamaian antar manusia seperti yang difirmankan Allah dalam surat an-Nisa' ayat 1;

\footnotetext{
${ }^{14}$ Hendi Suhendi, Fiqh Muamalah (Jakarta: PT Raja Grafindo Persada, 2010).

15 Ainul Yakin, Fiqh Muamalah (Pamekasan: Duta Media Publishing, 2010).

${ }^{16}$ Suhendi, Fiqh Muamalah.

${ }^{17}$ Kementerian Agama RI, Al-Qur'an dan Terjemahannya.
} 


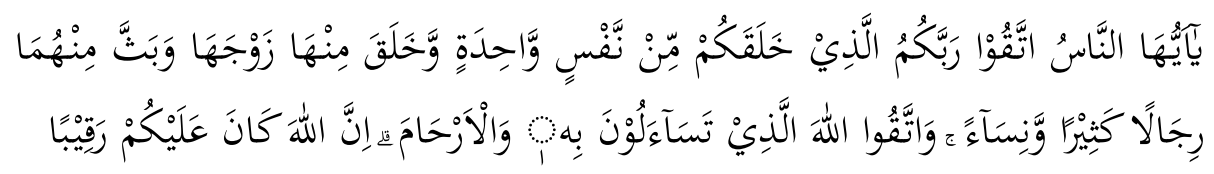

"Hai sekalian manusia, bertakwalah kepada Tuhan-mu yang telah menciptakan kamu dari seorang diri, dan dari padanya Allah menciptakan istrinya; dan dari pada keduanya Allah mengembangbiakkan laki-laki dan perempuan yang banyak. dan bertakwalah kepada Allah yang dengan (mempergunakan) nama-Nya kamu saling meminta satu sama lain, dan (peliharalah) hubungan silaturrahim. Sesungguhnya Allah selalu menjaga dan mengawasi kamu."

Ayat di atas menjelaskan mengenai pentingnya menjaga tali persaudaraan sesama umat manusia yang tujuanya menghindarkan seorang muslim dari perpecahan, atau mendatangkan musuh kepada muslim itu sendiri

\section{Riba}

Simpan pinjam erat kaitannya dengan istilah riba. Riba menurut Bahasa bermakna ziyadah (kelebihan atau tambahan). ${ }^{18}$ Secara linguistic, riba berarti tumbuh dan membesar. Menurut istilah teknis, riba beberapa pendapat yang menegaskan bahwa riba adalah pengambilan tambahan, baik dalam transaksi jual beli mupun pinjam meminjam secara batil atau bertentangan dengan prinsip muamalah dalam Islam. Dalam transaksi simpan pinjam dana secara konvensional, pemberi pinjman mengambil tambahan dalam bentuk bunga tanpa adanya suatu penyimpangan yang diterima peminjaman kecuali kesempatan dan faktor waktu yang berjalan selama proses peminjaman tersebut.

Menurut terminologi ulama fiqih mengenai riba, sebagaimana mazhab Hanabilah mendefinisikan riba adalah pertambahan sesuatu yang dikhususkan, sedangkan mazhab hanafiyah menjelaskan riba adalah tambahan pada harta pengganti dalam pertukaran harta dengan harta.

\footnotetext{
${ }^{18}$ Abdullah Saeed, Islamic Bankinh and Interest: A Study of The Prohibition Of Riba and Its Conyrmporary Interpretation (Leiden: Ej Brill, 1996) dalam Muhammad Syafi'I Antonio, Bank Syariah dari Teori ke Praktek (Leiden: Ej Brill, 2011).
} 
Riba adalah sesuatu yang haram, tidak ada perbedaan pendapat di kalangan ulama mengenai keharaman riba, dalam alQur'an firman Allah yang membahas riba disebutkan dalam beberapa tempat dan dalam waktu yang berbeda, orang yang biasa mempraktikkan riba biasanya ditandai dengan sifat rakus, bakhil, dan terlampau cermat dan mementingkan diri sendiri tanpa memperdulikan orang lain sehingga hal-hal seperti ini bisa melahirkan benih kebencian antar sesama umat manusia, hal ini berasal dari keterpaksaan orang untuk membayar riba. Oleh karena itu Allah Swt membenci dan melarang umat muslim untuk mempraktikkan tindak ini seperti. Firman Allah Q.S. al-Baqarah/2: $275: 19$

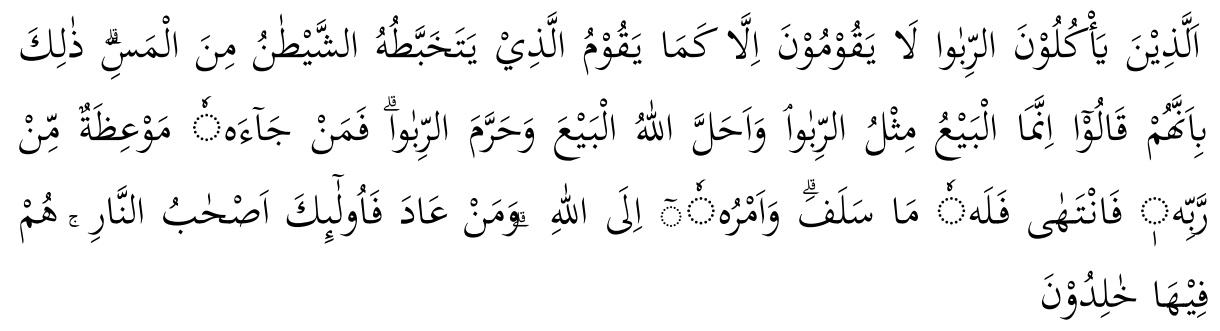

"Orang-orang yang Makan (mengambil) riba tidak dapat berdiri melainkan seperti berdirinya orang yang kemasukan syaitan lantaran (tekanan) penyakit gila. Keadaan mereka yang demikian itu, adalah disebabkan mereka berkata (berpendapat), Sesungguhnya jual beli itu sama dengan riba, Padahal Allah telah menghalalkan jual beli dan mengharamkan riba. orang-orang yang telah sampai kepadanya larangan dari Tuhannya, lalu terus berhenti (dari mengambil riba), Maka baginya apa yang telah diambilnya dahulu (sebelum datang larangan) dan urusannya (terserah) kepada Allah. orang yang kembali (mengambil riba), Maka orang itu adalah penghuni-penghuni neraka mereka kekal di dalamnya."

Ayat di atas menjelaskan bahwa siapa saja yang memberikan pinjaman baik berupa barang atau benda di jalan Allah, maka Allah akan melipat gandakan pinjaman gandakan tersebut berupa rezeki yang melimpah. Dalam hadist disebutkan setiap pinjaman yang di

${ }_{19}$ Abdullah bin Muhammad ath-Thayar, Ensiklopedi Fiqh Muamalah dalam Pandangan 4 Madzhab, Terj. Miftahul Khairi (Yogyakarta: Maktabah al-Hanif, 2009). 
dalamnya ada keuntungan, maka itu dihukum haram. Karena ariyah didasari oleh sifat tolong-menolong serta saling bantu-membantu dalam hal kebajikan.

Dalam sebuah hadist juga disebutkan bahwa Rasulullah Saw mencela beberapa pihak yang turut terlibat dalam muamalah yang tidak berkah ini, Jabir radhiyallahu 'anhu, Nabi shallallahu 'alaihi wa sallam bersabda 20

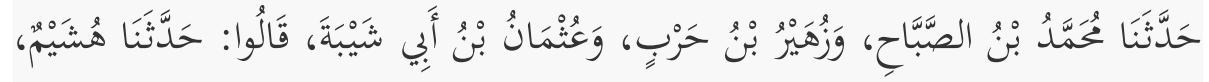

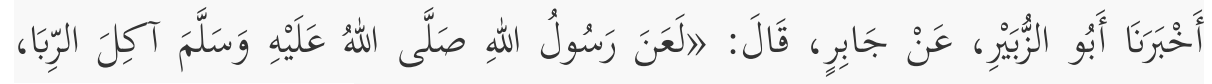

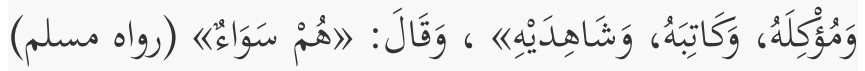

"Telah menceritakan kepada kami Muhamad bin Shabah dan Zubair bin Harb dan Utsman bin Abu Syaibag mereka berkata telah menceritakan kepada kami Husyaim telah mengabarkan kepada kami Abu Zubair dari Jabir berkata, Rasulullah shallallahu 'alaihi wa sallam melaknat pemakan riba, orang yang menyuruh makan riba, juru tulisnya dan saksi-saksinya, dia berkata mereka semua sama." (HR. Muslim dari Jabir)"21

Hadist di atas menjelaskan, setiap umat muslim tidak diperbolehkan bekerja sebagai sekretaris, petugas pembukuan, penerima uang, penyetor dan keseluruhan dari pihak-pihak yang melaksanakan atau mendukung riba tersebut terjadi. Sebab hadist di atas menunjukan ancaman bagi manusia atau semua pihak yang bekerjama melakukan riba, yaitu mendapat laknat Allah Swt dan rasulullah Saw yang berarti orang melakukan praktik riba mendapat celaan dan terjauhkan dari rahmat Allah Swt.

Tambahan yang dikenakan untuk transaksi pinjaman tanpa mempertimbangkan pemanfaatan berdasarkan tempo waktu, dan diperhitungkan secara pasti di muka persentase, maka praktik riba atau pembungaan saat ini telah memenuhi kriteria riba yang terjadi di zaman rasulullah Saw, baik riba nasi'ah ataupun fadhal dengan demikian praktek pembungaan uang ini termasuk bentuk riba, dan

\footnotetext{
${ }^{20}$ Farid Nu'man, Fiqih Praktis Sehari-Hari (Jakarta: gema insani press, 2019).

${ }^{21}$ Muslim bin Hajjaj Al-Naisaburi, Shahih Muslim (Beirut: Dar Ihya' al-Turats al-Arabiy, 2019).
} 
riba hukumnya haram. Praktik pembungaan uang ini banyak dilakukan oleh Bank, Asuransi, Pasar Modal, Pegadaian, Koperasi maupun individu.

Tambahan yang dikenakan untuk transaksi pinjaman tanpa mempertimbangkan pemanfaattan berdasarkan tempo waktu, dan diperhitungkan secara pasti di muka persentase, maka praktik riba atau pembungaan saat ini telah memenuhi kriteria riba yang terjadi di zaman rasulullah Saw, baik riba nasi'ah ataupun fadhal dengan demikian praktek pembungaan uang ini termasuk bentuk riba, dan riba hukumnya haram ${ }^{22}$

Riba terbagi menjadi empat macam yaitu riba nasiah (riba jahiliyyah), riba fadhal, riba qardhi, dan riba yadh. ${ }^{23}$ Riba Nasi'ah adalah tambahan yang diambil karena penundaan pembayaran hutang untuk dibayarkan pada tempo yang baru, sama saja apakah tambahan itu merupakan sanksi atas keterlambatan pembayaran hutang atau sebagai tambahan hutang baru.

Riba fadhal adalah riba yang diambil dari kelebihan pertukaran barang yang sejenis yang barangnya sama, tetapi jumlahnya berbeda. Atau jual beli dalam jenis barang tertentu seperti emas perak serta beberapa bahan pangan seperti gandum, kurma, dan garam yang mana tidak sesuai dengan perintah Rasulullah SAW.

Riba Yadh adalah jual beli yang dilakukan seseorang sebelum menerima barang yang dibelinya dari sipenjual dan tidak boleh menjualnya lagi kepada siapapun, sebab barang yang dibeli belum diterima dan masih dalam ikatan jual beli yang pertama. Dengan kata lain, kedua belah pihak yang melakukan pertukaran uang atau barang telah berpisah dari tempat akad sebelum diadakan serah terima. Sedangkan riba Qardhi adalah meminjam uang kepada seseorang dengan syarat kelebihan atau keuntungan yang harus diberikan oleh peminjam kepada pemberi pinjaman dengan tujuan mengeksploitasi kekayaan orang lain dan mencari keuntungan tanpa berbuat apapun. ${ }^{24}$

\footnotetext{
${ }^{22}$ Yuliantini, "Studi Tentang Sistem Penerapan Fatwa Bunga Bank di Indonesia," Jurnal Kajian Hukum Islam dan Sosial Kemasyarakatan 11, no. 2 (2011).

${ }^{23}$ Abd Shomad, Hukum Islam Penormaan Prinsip Syariah dalam Hukum Islam (Jakarta: Kencana, 2012).

24 Syamsul Effendi, "Riba dan Dampaknya Dalam Masyarakat dan Ekonomi," Jurnal Ekonomi dan Bisnis 18, no. 2 (2018).
} 
Islam sangat melarang adanya tambahan pembayaran Ketika mengembalikan pinjaman, karena salah satu dampak buruk bisa dimanfaatkan untuk mendapatkan keuntungan padahal pihak peminjam sedang mengalami kesulitan, melihat fenomena semacam ini sangat memprihatinkan. ${ }^{25}$ Riba dianggap menimbulkan masalah dibandingkan menyediakan suatu solusi dalam mengatasi persoalan ekonomi atau finansial, bahkan riba di anggap sebagai malapetaka besar jika terlibat dalam transaksi haram ini. Berikut adalah pendapat para ulama yang menjelaskan sebab-sebab diharamkan riba dalam Islam sebagai berikut;

1. Pemaksaan, dalam pinjam meminjam terdapat satu sikap kerelaan dalam membantu sesama jika orang tersebut mengalami permasalahan finansial, namun yang ada di dalam riba adalah pemaksaan kepada satu pihak terhadap pihak lain, karena kelebihan yang mereka bayarkan tidak mendapatkan imbalan, hal-hal seperti ini sangat bertentangan dengan prinsip muamalah,

2. Adanya uang dalam Islam adalah sebagai alat transaksi bukan menjadi komoditas yang diperjualbeilkan, jika uang menjadi tujuan maka manusia akan menjadi malas tidak ada kerja keras, tidak ada peningkatan pengetahuan dan kebudayaan orang untuk menyimpan dan membungakan uang mereka.

3. Riba memyebabkan hilangnya kasih sayang, bahkan sebaliknya riba bisa menimbulkan sifat dendam, dengki, dan iri hati. Karena yang kaya selalu senantiasa berusaha meningkatkan jumlah uang mereka sedangkan yang miskin akan semakin tercekik dengan adanya beban yang semakin berat.

Pendapat lain dari Ar-Razi mengemukakan alasan-alasan pelarangan riba sebagai berikut;26

\footnotetext{
25 Tri Setiawati, "Riba dalam Pandangan Al-Qur'an dan Hadits," Jurnal al-intaj 3, no. 2 (2017).

${ }^{26}$ Abd Anshori, Perbankan Syariah di Indonesia (Yogyakarta: Gadjah Mada University, 2018).
} 
1. Riba adalah perampasan hak milik orang lain tanpa nilai imbangan, transaksi yang bercampur dengan riba sama halnya merampas harta orang lain karena salah satu pihak menerima kelebihan tanpa harus mengeluarkan apa-apa sehingga mencerminkan tranksaksi yang tidak adil.

2. Riba terlarang karena menghalangi orang untuk ikut serta dalam profesi aktif

3. Riba menimbulkan ketegangan di antara sesama manusia, rasa yang tulus dalam membantu sesame manusia hilang bila sifat egoisme pembungaan uang sudah merasuk ke dalam hati seseorang. Sehingga rasa kebincian dan permusuhan hadir tengah kehidupan manusia, yaitu permusuhan antara kelompok miskin dengan kelompok kaya.

4. Riba adalah perjanjian yang digunakan oleh kelompok yang kaya untuk mengambil kelebihan modal, sehingga kelompok yang kata tetap kaya dan kelompok miskin akan tetap miskin, sebagaimana kita ketahui pihak yang kaya akan memperoleh suku bunga yang tinggi sementara modal menjadi sangat mahal, bagi yang miskin menjadi tidak mampu melakukan peminjaman dan tidak dapat berusaha maka berakibat akan semakin jauh tertinggal

5. Keharaman riba ditetapkan oleh Al-Qur'an dan manusia tidak harus mengetahui alasanya.

Penjelasan di atas, riba adalah suatu usaha mengeksploitasi kekayaan atau harta orang lain, yaitu kelompok atau individu yang kaya kepada kelompok miskin dengan cara yang tidak baik. riba juga merusak akal, dan hati manusia tetapi juga merusak roda perekonomian bangsa

Kajian Hukum Islam Terhadap Praktik Simpan Pinjam di Kerukunan Kayubulan Kota Manado

Kerukunan kayubulan merupakan perkumpulan orang-orang yang melakukan simpan pinjam. Kerukunan kayubulan ini didirikan sejak tanggal 21 Februari 1991 oleh bapak H. Rum Usulu dan rekannya bapak H. Yusuf Ali. Dinamakan kerukunan kayubulan karena kerununan yang artinya rukun antara keluarga sedangkan kayubulan ialah keluarga yang terdapat dalam kerukunan ini megambil nama suatu daerah asal mereka. 
Perkembangan kerukunan kayubulan tidak secara instan tetapi melalui proses yang Panjang, mendapatkan orang untuk menjadi anggota kayubulan dilakukan dengan cara persuasif atau membujuk. Ini dilakukan agar orang-orang tertarik mengikuti atau masuk menjadi anggota kayubulan, maka dengan bertambahnya anggota informasi tentang kerukunan kayubulan dan kegiatan di dalamnya pun meluas. Berdasarkan wawancara dari anggota kayubulan mereka masuk menjadi anggota melalui informasi sesama profesi yang telah menjadi anggota kayubulan dan ada juga mereka yang masuk di kerukunan kayubulan hasil ajakan dari keluarga yang sudah mengikuti kerukunan sebelumnya.

Berdasarkan wawancara dari ketua Bapak H. Rum kerukunan simpan pinjam Kayubulan Kota Manado bahwasanya pihak kerukunan menetapkan aturan kepada seluruh anggota kerukunan harus saling membantu sesama anggota lainya, maka dengan adanya simpan pinjam ini bunga yang mereka dapatkan Ketika membayar pinjaman diakhir penerimaan pasti akan diterima meskipun tidak seratus persen. Dana simpan pinjam pada kerukunan Kayubulan yang dikumpulkan secara Bersama dan dipinjamkan kepada anggota yang memerlukan pinjaman dengan jumlah yang berbeda-beda untuk tiap anggota. Anggota yang ingin mengajukan pinjaman harus membuat permohonan tertulis kepada pengurus dengan mencantumkan jumlah uang yang diperlukan.

Setelah mengajukan permohonan pinjaman selanjutnya pengurus akan mempertimbangkan jumlah dari setiap pinjaman yang diajukan, adapun syarat-syarat dalam pengembaliannya akan dibayarkan sesuai aturan di kerukunan kayubulan. Kerukunan kayubulan mempunyai aturan yang mengikat seperti yang terjadi sebelum covid-19 jika ada keterlembatan menabung maka akan dikenakan denda 15.000 ribu rupiah dan harus dibayarkan dijam 17:00 WITA, dan anggota yang memiliki pinjaman belum mampu menbayar pinjaman tersebut di hari yang ditentukan maka anggota tersebut wajib membayar bunganya.

Kerukunan kayubulan memberlakukan kewajiban untuk mempunyai buku tabungan, dan jumlah buku tabungan yang dimiliki tiap anggota berbeda-beda, buku tabungan yang dimili anggota muali dari satu buku sampai dengan 3 buku tabungan. Berdasarkan 
wawancara dari dari salah satu anggota yaitu Ibu Nurhayati Halim:27 "saya (ibu Nurhayati Halim) mengikuti kerukunan kayubulan sudah kurang lebih dua puluh tahun, dengan simpanan Rp.300.000 mengisi sebanyak lima puluh dua kali dalam setahun jadi total simpanan ibu nurhayati halim 15.600.000 (limabelas juta enam ratus rupiah) yang wajib untuk di simpan. Selain mengisi tabungan saya diwajibkan meminjam selama 5 kali dalam satu periode atau 52 minggu. Setiap pengembalian pinjaman disetorkan dengan tambahan 10 persen dari jumlah pinjaman yang dipinjam, misalnya saya meminjam sebesar Rp.10.000.000 maka yang harus saya kembalikan ialah 1.100.000 disetorkan selama 10 kali.

Simpan pinjam dalam Islam dikenal dengan Ariyah. Ariyah bisa diartikan perbuatan berupa pemberian milik untuk sementara waktu oleh seseorang kepada pihak lain, agar penerima dapat memanfaatkan serta mengambil manfaat dari harta yang diberikan tanpa harus membayar imbalan. Akad ariyah secara tidak langsung berhubungan dengan akad qardh, wadiah, namun menjadi pembedanya adalah akad ariyah bisa dilaksanakan dengan adanya jaminan seperti uang tabungan, atau harta yang dititipkan.

Karakter dari ariyah yaitu harta yang dipinjamkan memiliki kesamaan dengan harta yang dititipkan. ${ }^{28}$ Simpan pinjam yang terjadi dikerukunan kayubulan dimana para anggota memiliki buku tabungan sebagai pegangan dan dalam buku tersebut ditulis pinjaman dari setiap anggota agar tidak terjadi kesalapahaman ketika penerimaan uang simpanan. Pihak kerukunan memberikan pinjaman tanpa ada batasan jumlah dalam pengajuan pinjaman uang tersebut. hal ini merupakan salah satu unsur tolong menolong seperti dalam sebagaimana Allah berfirman dalam Q.S. al- Maidah/5: 2

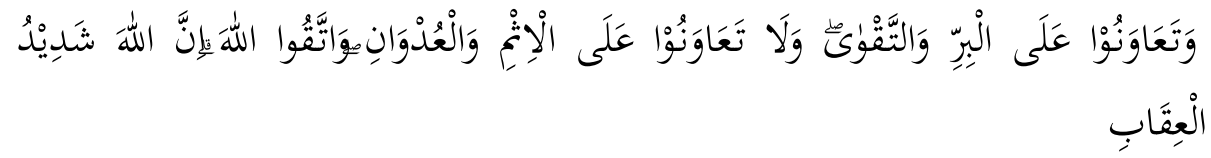

\footnotetext{
${ }^{27}$ Hasil Wawancara dengan Anggota Kerukunan Kayubulan Manado Ibu Nurhayati Halim pada tanggal 13 April 2021, di Kediaman Wonasa kota Manado.

${ }^{28}$ Jamaluddin, Konsekuensi Akad AL-Ariyah dalam Fiqh Muamalah Maliyah Perspektif Ulama Madzhab Al-Arba'ah,” Jurnal Qawani 2, no. 2, (Juli 2018), 9.
} 
Kajian Hukum Islam Terhadap Praktik Simpan Pinjam

di Kerukunan Kayubulan Kota Manado

"Dan tolong-menolonglah kamu dalam (mengerjakan) kebajikan dan takwa, dan jangan tolong-menolong dalam berbuat dosa dan pelanggaran. Dan bertakwalah kamu kepada Allah, sesungguhnya Allah amat berat siksa-Nya". ${ }^{29}$

Ayat di atas menjelaskan, secara nyata disebutkan perbuatan tolong-menolong tidak mutlak berlaku untuk semua perbuatan. Ayat di atas mengungkapkan bahwa dalam lapangan perbuatan yang bersifat tercela tolong menolong itu dilarang oleh syariat. Simpan pinjam di kerukunan kayubulan Kecamatan Wanea Kota Manado sering membantu anggota dalam hal pinjaman jika anggota yang mengalami masalah yang membutuhkan dana yang besar anggota bisa mengajukan pinjaman kepada pihak kerukunan tanpa ada Batasan minimal dalam pinjaman tersebut. artinya rasa tolong menolong yang ada dikerukunan kayubulan sangatlah tinggi. tetapi yang harus diketahui tolong-menolong haruslah sesuai dengan syariat.

Setiap bermuamalah haruslah memperhatikan setiap rukun dan syarat yang terdapat dalam simpan pinjam yaitu adanya orang yang memberikan pinjaman, adanya orang yang meminjam, dan lafal dalam pinjaman. Ulama fikih menjelaskan, bahwa syarat-syarat dalam akad ariyah antara lain para pihak yang meminjam harus berakal dan capak bertindak atas nama hukum, karena pihak yang meminjam tidak berakal maka tidak dapat memegang amanat. Oleh karena itu, anak kecil, orang gila,dungu (cacat mental) tidak bisa mengadakan akad ariyah. Objek atau barang yang akan dipinjamkan, bukan barang yang apabila dipinjamkan maka akan habis, seperti makanan dan minuman. Objek atau barang yang akan dipinjamkan harus secara langsung dapat dikuasai oleh peminjam dan kemudian bisa diambil manfaat dari objek tersebut secara langsung.

Begitupun yang terjadi dikerukunan kayubulan Kecamatan Wanea Kota Manado, dalam hal ini akad (perjanjian) ariyah hanya melalui lisan anggota dan pihak pengurus menuliskan dibuku pengajuan pinjaman, namun peminjam harus menunggu selama satu minggu agar pinjaman bisa diterima. Dalam agama tidak

${ }^{29}$ Kementerian Agama RI, Al-Qur'an dan Terjemahannya (Bandung: PT Cordoba Internasional Indonesia, 2016), 50. 
memberikan ketentuan khusus untuk tetang lafaz yang harus dipakai. Ini berarti bahwa pinjam dan yang meminjamkan boleh saja menggunakan lafaz apa saja, tetapi harus menggambarkan adanya transaksi pinjam meminjam. Hal seperti ini diserahkan kepada adat kebiasaan yang berlaku.

Berdasarkan peneltian yang dilakukan dapat dipahami dalam pelaksanaan rukun simpan pinjam kerukunan kayubulan kecamatan wanea kota Manado sudah sesuai dan benar sesuai karena sudah menggambarkan adanya transaksi pinjam meminjam. Namun menjadi masalah adalah syarat, ini berkaitan dengan syarat yang ketiga objek atau barang yang dipinjamkan harus secara langsung di kuasai oleh peminjam dan kemudian dapat di manfaatkam secara langsung pula, jika kita lihat peminjam harus menunggu selama satu minggu baru uang tersebut bisa miliki dan dimanfaatkan artinya syarat yang Ketiga tidak tercapai.

Islam mengajarkan jika meminjam suatu barang untuk dimanfaatkan untuk dirinya sendiri maka harus mengembalikan barang tersebut, di kerukunan kayubulan sesuai dengan hasil penelitian semua anggota telah sesuai perintah syariat untuk mengembalikan pinjaman tersebut sesuai dengan akad di awal, namun untuk beberapa anggota yang belum mampu mengembalikan pinjaman tersebut maka anggota akan memberitahukan kepada pihak kerukunan, selanjutnya pihak kerukunan lah yang akan menentukan apa yang harus dilakukan, Dan pihak peminjam memberikan pinjaman disertakan dengan bunga sebesar duapuluh persen. Jadi anggota mempunyai etika baik dalam melunasi pinjaman tersebut namun berbeda dengan pihak kerukunan kurangnya rasa tolongmenolong.

Pada praktiknya selain penulisan pengajuan pinjaman pihak kerukunan kayubulan menerapkan aturan bahwa setiap anggota menyetorkan pinjaman selama sepuluh kali dalam sepuluh minggu dengan bunga sebesar sepuluh persen. Jika dalam menyetorkan uang pinjaman anggota mengalami ke dalam atau hambatan, maka akan membayar bunga terlebih dahulu. Allah swt melarang setiap muslim untuk mengambil bunga di setiap pinjaman yang dilakukan. Dan Allah swt melarang membelanjakan uang hasil riba untuk membeli barang lalu menggunakan barang tersebut. praktik riba yang terjadi 
di kerukunan kayubulan sangat bertentangan dengan firman Allah di atas.

Dosa riba salah dari tujuh macam dosa besar, riba disejajarkan dengan syirik, sihir, pembunuhan dan memakan harta anak yatim. Ini menunjukan bahwa riba sangat tidak dikehendaki oleh ajaran islam, karena riba merugikan orang lain. Siapapun yang melakukan praktik riba, baik sebagai juru tulisnya, saksinya atau pelaku ribanya juga digolongkan orang yang berbuat dosa. Disebutkan juga dalam hadist Nabi saw mengenai pelarangan mencampurkan unsur riba dalam muamalah

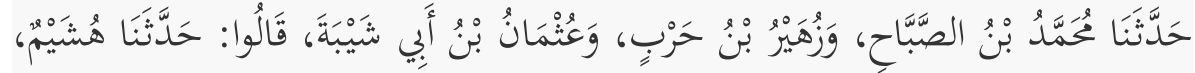

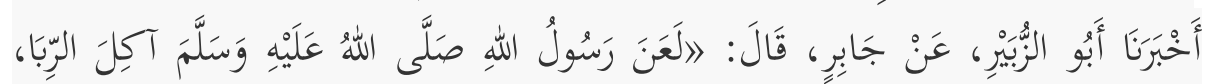

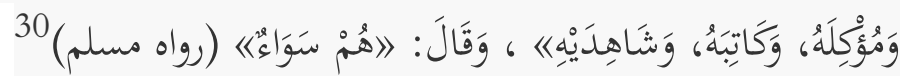

"Telah menceritakan kepada kami Muhamad bin Shabah dan Zubair bin Harb dan Utsman bin Abu Syaibag mereka berkata telah menceritakan kepada kami Husyaim telah mengabarkan kepada kami Abu Zubair dari Jabir berkata, Rasulullah shallallahu 'alaihi wa sallam melaknat pemakan riba, orang yang menyuruh makan riba, juru tulisnya dan saksi-saksinya, dia berkata mereka semua sama.." (HR. Muslim dari Jabir)"

Penulis mendapati bahwa pihak kerukunan dan anggota telah mengetahui bahwa riba sesuatu yang di haramkan, seperti halnya riba ariyah yaitu meminjam uang kepada seseorang dengan syarat ada kelebihan atau keuntungan ketika pelunasan pinjaman tersebut. seperti yang terjadi dalam permasalahan dikerukunan kayubulan Wanea kota Manado. Permasalahan utama yang ada dikerukunan kayubulan adalah tambahan yang dikenakan dari pihak pemberi pinjaman yaitu pengurus kerukunan sebesar 10 persen.

Seperti yang diungkapkan oleh ibu Nurhayati Halim yang meminjam dikerukunan kayubulan sebesar RP. 10.000.000 dan harus mengembalikan tiap minggunya 1.100 .000 selama 10 kali, dengan simpanan Rp. 300.000 rupiah, dan Ketika tidak bisa membayar uang simpanan maka, atau masalah bunga yang dirasakan oleh ibu

${ }^{30}$ Muslim bin Hajjaj al-Naisaburi, Shahih Muslim, Juz III (Bairut: Dar Ihya' al-Turats alArabiy, t.th), 1219. 
Rahmawati Halim yang mempunyai simpanan sebesar 300.000 dan pinjaman 10.000.000 dengan bunga sepeluh persen dengan pengembalian sebanyak sepuluh kali jadi yang harus dibayark oleh ibu Rahmawati Halim adalah 1.100.000 rupiah.

Di kerukunan wajib membayar terlebih dahulu bunga jika tidak mampu membayar pinjaman pokok pada minggu yang diadakannya simpan pinjam ini. Ini terjadi sesuai dengan kesepakatan di awal antara peminjam dan pemberi pinjaman, akad nya telah jelas dan tidak ada disembunyikan dari pihak pemberi pinjaman namun hukumnya tidak diperbolehkan dalam islam.

Mengenai tambahan yang dibebankan pihak kerukunan kepada anggota sangat bertentangan dengan prinsip-prinsip dari hukum Islam sendiri yang mana prinsip tauhid (keesahaan tuhan) yang dimana menjadi orientasi umat muslim untuk bermuamalah agar mematuhi aturan Allah tetapi dengan adanya campuran riba dalam kegiatan mauamalah maka sangat bertentangan dengan fatwa MUI tanggal 22 syawal 1424 H/6 Desember 2003, kemudian prinsip yang kedua adalah keseimbangan yang tujuannya adalah membentuk paradimga seorang muslim bahwasanya sikap keseimbangan bisa membawa dan menghantarkan seorang muslim kepada satu keadaan ada fungsi sosial yang bercerminkan keadilan, kesederhanaan, dan jauh dari sifat boros tetapi jika seorang muslim mempraktikan atau mengambil bunga setiap kegiatan muamalahnya maka konsep keseimbangan sangat jauh dari seorang muslim itu, yang ketiga konsep tawa' un (tolong menolong) tolong menloong menjadi ideologi sangat penting dalam setiap kegiatan manusia seperti muamalah sendiri, seorang hendaknya menjauhi dari riba karena konsep islam mengajarkan tolong menolong bukan mengambil harta saudara muslimnya dengan cara-cara bathil.

Simpan pinjam di kerukunan Kayubulan Kota Manado sejak awal akad telah menentukan berapa besar bunga pinjaman, jika kita lihat teori dari Prof. Dr, Wahbah Az-Zuhaili mengenai pinjaman yang mendatangkan keuntungan hukumnya haram, jika keuntungan itu diisyaratkan sebelumnya dan bukan merupakan tradisi yang mendatangkan keurungan dan haram hukumnya mengambil manfaat dari harta pinjaman, seperti menaiki hewan tunggangannya dan presentase bunga telah ditentukan sejak awal, baik bagi nasabah maupun bagi peminjam. Kemudharatan bunga telah terwujud secara 
jelas, sehingga hukumnya adalah haram. Bunga seperti itu riba dan dosanya seperti dosa riba. Maka simpan pinjam di kerukunan jelas mempraktikkan riba setiap transaksi.

Implikasi simpan pinjam kerukuna Kayubulan Kota Manado dapat penulis Tarik dari penelitian ini adalah, dengan adanya pinjaman anggota kerukunan yang mengalami masalah bisa mengajukan pinjaman kepada kerukunan dengan jumlah yang sangat besar seperti anggota yang membutuhkan dana untuk membuka usaha, anggota yang membutuhkan dana dalam rangka menyekolahkan anak mereka sampai membantu salah satu keluarga anggota untuk berobat. Kesempatan digunakan oleh anggota untuk menyelasaikan masalah mereka masing-masing namun masalah pada simpan pinjam kerukuan adalah masih adanya praktik riba ini.

Riba tidak akan mendatangkan hikmah bagi seorang muslim karena Allah melaknat bagi orang yang mempraktikan riba, umat muslim yang mempraktikan riba pastinya Allah saw tidak akan meridhoi rizki yang diperoleh dan tidak mendapatkan pahala, dan umat muslim yang mempraktikan riba pasti akan mendatangkan musuh untuk dirinya sendiri. Praktik simpan pinjam di kerukunan kayubulan yang memungut bunga dari pinjaman sebesar 10 persen tidak sesuai dengan prinsip-prinsip hukum islam sendiri, karena prinsip tauhid (keeshaan) yang mewajibkan setiap umat muslim mematuhi perintah Allah tetapi dilanggar dengan memberikan tambahan atau bunga disetiap transaksi, kedua praktik simpan pinjam dkerukunan kayubulan tidak seusai dengan prinsip keseimbangan karena dengan adanya tambahan di dalam transaksi tidak mencerminkan tujuan prinsip keseimbangan, dan praktik simpan pinjam dikerukunan kayubulan tidak sesuai dengam prinsip hukum islam yaitu tolong-menolong sebab dengan adanya tambahan di dalam transaksi simpan pinjam.

Selain pada bunga tambahan terdapat pula denda yang dikenakan kepada setiap anggota yang terlambat menyetor atau yang tidak dapat hadir pada saat hari penyetoran. Dalam penerapan denda setiap anggota sudah mengetahui sejak awal mengikuti kerukunan kayubulan. Dalam rangka meningkatkan perekonomian umat maka hendaknya seluruh aktivitas perekonomian agar tidak melakukan praktik ribawi karena kegiatan seperti bukan memajukan perekonomian tetapi bisa menghancurkan roda perekonomian umat. 
Tentu pentingnya fatwa dan sosialisasi nya oleh para ulama bisa sebagai pendekatan religius, Diharapkan kegiatan simpan pinjam kerukunan Kayubulan haruslah simpan pinjam yang berpedoman pada ketentuan Islam dan meninggalkan sistem simpan pinjam konvensional. Dan juga pentingnya followup atau tindak lanjut dari dari fatwa itu sendiri bukan hanya semata tanggung jawab dari pihak Lembaga keuangan atau orang-orang yang terlibat langsung di dalamnya, melainkan tanggung jawab seluruh komponen-kompenen, termasuk pemerintah, dan para ulama maupun lembaga-lembaga Pendidikan, serta komponen lainya.

\section{Penutup}

Dari seluruh pembahasan yang telah dikemukakan, maka dapat ditarik kesimpulan sebagai berikut;

Praktik simpan pinjam di kerukunan Kayubulan Kecamatan Wanea Kota Manado Ketika menjadi anggota baru maka harus membayar saham sesuai aturan dari pihak kerukunan kayubulan, kerukunan mewajibkan juga untuk menabung setiap minggu dengan jumlah simpanan yang bervariatif, dan kerukunan mewajibkan untuk mengajukan pinjaman sebanyak empat kali dalam satu periode, dengan menggunakan akad secara lisan dan pihak kerukunan mencatat jumlah pinjaman tersebut juga menambahkan bunga pinjaman Ketika akad sebesar sepuluh persen.

Tinjauan Hukum Islam terhadap praktik simpan pinjam kerukunan Kayubulan Kecamatan Wanea Kota Manado, dimana pihak pemberi pinjaman menerapkan tambahan atau bunga dan pihak penerima pinjaman menerima tambahan tersebut maka tambahan tersebut menjadi keuntungan bagi pihak kerukunan kayubulan. Hal ini jelas mengandung ribawi, sebagaimana yang telah kita ketahui kegiatan muamalah yang mengandung riba maka hukumnya diharamkan oleh Allah swt dalam Alquran dan hadis Nabi saw.

\section{Daftar Pustaka}

Abdullah bin Muhammad ath-Thayar. Ensiklopedi Figh Muamalah dalam Pandangan 4 Madzhab, Terj. Miftahul Khairi. Yogyakarta: Maktabah al-Hanif, 2009.

Al-Bukhari, Muhammad bin Ismail. Shahih al-Bukhari. 3 ed. Damaskus: Dar Thuqar al-Nujat, 2020. 
Al-Naisaburi, Muslim bin Hajjaj. Shahih Muslim. Beirut: Dar Ihya' alTurats al-Arabiy, 2019.

Anshori, Abd. Perbankan Syariah di Indonesia. Yogyakarta: Gadjah Mada University, 2018.

Az-Zuhaili, Wahbah. , Fiqih Islam Wa Adillatuhu. Jakarta: PT Gema Insani, 2011.

Dasim, Yusnita. "Mekanisme Simpan Pinjam Di Koperasi Sinar Mas dalam Perspektif Hukum Islam Studi Kasus Koperasi Simpan Pinjam Mas sinar Kelurahan calaca." Al-syir'ah 3, no. 1 (2005).

Effendi, Syamsul. "Riba dan Dampaknya Dalam Masyarakat dan Ekonomi." Jurnal Ekonomi dan Bisnis 18, no. 2 (2018).

Hasan. Berbagai Macam Transaksi dalam Islam. Jakarta: PT Raja Grafindo Persada, 2013.

Jamaluddin. "Konsekuensi Akad AL-Ariyah dalam Fiqh Muamalah Maliyah Perspektif Ulama Madzhab Al-Arba'ah." Jurnal Qawanin 3, no. 2 (2018).

Karim, Helmi. Fiqih Muamalah. Jakarta: PT Raja Grafindo Persada, 2020.

Karimi, Miftahul. Ensilikopedia Fiqih Muamalah dalam Pandangan 4 Madzhab. Yogyakarta: Maktabah al-Hanif, 2009.

Kementerian Agama RI. Al-Qur'an dan Terjemahannya. 1 ed. Bandung: PT Cordoba International Indonesia, 2016.

Nu'man, Farid. Fiqih Praktis Sehari-Hari. Jakarta: gema insani press, 2019.

Nurhaidi. “Islamisasi Koperasi Simpan Pinjam." Jurnal ekonomi 28, no. 2 (2017).

Saeed, Abdullah. Islamic Bankinh and Interest: A Study of The Prohibition Of Riba and Its Conyrmporary Interpretation (Leiden: Ej Brill, 1996) dalam Muhammad Syafi'I Antonio, Bank Syariah dari Teori ke Praktek. Leiden: Ej Brill, 2011.

Setiawati, Tri. "Riba dalam Pandangan Al-Qur'an dan Hadits." Jurnal al-intaj 3, no. 2 (2017).

Shiddiq, Abdul Rahman Ghazaly, Ghufron Ihsan, Sapludin. Fiqh Muamalat. Jakarta: Kencana, 2010.

Shomad, Abd. Hukum Islam Penormaan Prinsip Syariah dalam Hukum Islam. Jakarta: Kencana, 2012.

Suhendi, Hendi. Fiqh Muamalah. Jakarta: PT Raja Grafindo Persada, 2010. 
Yakin, Ainul. Fiqh Muamalah. Pamekasan: Duta Media Publishing, 2010.

Yuliantini. "Studi Tentang Sistem Penerapan Fatwa Bunga Bank di Indonesia." Jurnal Kajian Hukum Islam dan Sosial Kemasyarakatan 11, no. 2 (2011). 